\title{
PENGARUH PENGETAHUAN, MOTIVASI DAN PERSEPSI RISIKO TERHADAP PERILAKU PENGGUNAAN ALAT PELINDUNG DIRI DASAR YANG DIMODERASI FAKTOR PENGAWASAN PADA CIVITAS HOSPITALIA RSGMP UNSOED
}

\author{
Cita Chusnul Chotimah'1, Haryadi², Nendyah Roestijawati ${ }^{3}$ \\ 1,2,3 Magister Manajemen, Fakultas Ekonomi dan Bisnis, Universitas Jenderal Soedirman, Indonesia \\ *Email corresponding author: citachotimah@gmail.com
}

\begin{abstract}
Abstrak
Salah satu program pencegahan dan pengendalian infeksi nosokomial pada tenaga kesehatan rumah sakit yaitu dengan menggunakan Alat Pelindung Diri Dasar. Hasil survei terakhir pada bulan Juli 2018 yang dilakukan oleh tim Pencegahan dan Pengendalian Infeksi (PPI) RSGMP Unsoed menemukan beberapa kendala dalam penerapan perilaku penggunaan APD dasar oleh tenaga kesehatan di RSGMP Unsoed diantaranya masih kurangnya kesadaran tentang pentingnya penggunaan APD dasar saat melakukan tindakan, jumlah pasien yang melonjak sehingga membuat tenaga kesehatan enggan untuk mengganti APD dasar karena dirasa membuang waktu dan cost, maupun keterlambatan atau ketidaktersediaan pihak manajemen dalam menyediakan APD dasar. Berdasarkan latar belakang tersebut, tujuan penelitian ini adalah untuk mengetahui pengaruh pengetahuan, motivasi dan persepsi risiko tentang penggunaan alat pelindung diri dasar terhadap perilaku penggunaan alat pelindung diri dasar yang dimoderasi faktor pengawasan pada civitas hospitalia RSGMP Unsoed. Responden pada penelitian ini adalah 127 orang dengan teknik proportionate random sampling, yang diwawancara dengan instrumen berupa kuesioner. Alat analisis penelitian ini adalah regresi moderasi (Moderating Regression Analysis) dengan memanfaatkan program SPSS. Hasil penelitian menunjukkan terdapat pengaruh pengetahuan, motivasi dan persepsi risiko terhadap perilaku penggunaan APD dasar. Pengawasan memoderasi pengaruh pengetahuan dan motivasi terhadap perilaku penggunaan APD dasar, namun tidak memoderasi pengaruh persepsi risiko terhadap perilaku penggunaan APD dasar.

Kata Kunci: Pengetahuan, Motivasi, Persepsi Risiko, Pengawasan, Perilaku, Alat Pelindung Diri Dasar
\end{abstract}

\begin{abstract}
One of the nosocomial infection prevention and control programs on hospital health workers by wearing Personal Protective Equipment. The recent survey in July 2018 conducted by the Infection Prevention and Control team (PPI) of RSGMP Unsoed found several obstacles in the behaviour in the usage of PPE by health workers in RSGMP Unsoed: the lack of awareness of the importance of wearing PPE during treatment, health workers were reluctant to replace PPE and found it as "waste of time and cost" due to the soaring number of patients, or the delayed and unavailability of the PPE provided by the hospital management Based on that introduction, this research aimed to identify the effect of knowledge, motivation and risk perception of the use of Personal Protective Equipment (PPE) on the behaviour in the usage of PPE among healthcare workers in RSGMP Unsoed moderated by supervision factors. The study included 127 respondents with proportionate random sampling were interviewed using a questionnaire. The analysis tool of this study was Moderated Regression Analysis (MRA) by utilizing the SPSS program. The result shows there are effects of knowledge, motivation and risk perception of the use of Personal Protective Equipment (PPE) on the behaviour in the usage of PPE. Supervision of the behaviour in the usage of PPE moderates the effect of knowledge and motivation of the use of PPE on the behaviour in the usage of PPE, but does not moderate the effect of risk perceptions of the use of PPE on the behaviour in the usage of PPE.

Keywords: Knowledge, Motivation, Risk Perception, Supervision, Behaviour, Personal Protective Equipment.
\end{abstract}

\section{PENDAHULUAN}

Salah satu program pencegahan dan pengendalian infeksi nosokomial pada tenaga kesehatan rumah sakit yaitu dengan cara melaksanakan standar keselamatan pasien dengan menggunakan Alat Pelindung Diri (APD) (Darmadi, 2008). Perilaku penggunaan APD oleh tenaga kesehatan selama bekerja di rumah sakit menurut beberapa penelitian, masih menunjukkan angka kepatuhan yang belum mencapai standar. Shara (2014) menyatakan hanya 5\% tenaga kesehatan yang taat dalam menggunakan sarung tangan, masker, baju pelindung dan kaca mata pelindung 
secara rutin Hal ini menunjukkan bahwa tingkat perilaku penggunaan APD oleh tenaga kesehatan masih tergolong cukup rendah.

Data perilaku kepatuhan penggunaan APD dasar yang kurang stabil merupakan masalah yang kompleks karena dipengaruhi oleh berbagai macam faktor perilaku, diantaranya faktor pengetahuan, motivasi, persepsi risiko dan pengawasan. Pengetahuan tenaga kesehatan tentang APD dasar akan mendukung tenaga kesehatan untuk patuh menggunakan APD selama bekerja (Geller, 2001). Motivasi tenaga kesehatan dalam menggunakan APD sangat diperlukan dalam proses kerja, karena seseorang yang tidak mempunyai motivasi menggunakan APD, tidak akan mungkin menggunakan APD secara benar sesuai fungsinya (Wijayanto, 2015). Persepsi yang keliru dapat meningkatkan kemungkinan tenaga kerja berperilaku yang tidak aman dalam menghadapi risiko (Rusmerie, 2016; Sakinah, 2017). Selain itu, tidak adanya petugas khusus yang melaksanakan pengawasan terhadap perilaku penggunaan APD, pengawasannya pun terbatas hanya pada pekerjaan yang dilakukan bukan pengawasan terhadap perilaku penggunaan APD karena tenaga kerja merasa penggunaan APD bukan suatu kewajiban yang harus dilaksanakan.

Berdasarkan latar belakang tersebut, tujuan penelitian ini adalah untuk mengetahui pengaruh pengetahuan, motivasi dan persepsi risiko tentang penggunaan alat pelindung diri dasar terhadap perilaku penggunaan alat pelindung diri dasar yang dimoderasi faktor pengawasan pada civitas hospitalia RSGMP Unsoed.

\section{TINJAUAN PUSTAKA DAN PERUMUSAN HIPOTESIS}

\section{Perilaku}

Menurut Notoatmodjo (2007) perilaku berasal dari bahasa inggris "behavior" yang artinya semua kegiatan atau aktivitas makhluk hidup yang dapat diamati secara langsung maupun yang tidak dapat diamati secara langsung oleh pihak luar. Perilaku dapat dibedakan menjadi dua berdasarkan bentuk respon terhadap stimulus yaitu perilaku tertutup dan perilaku terbuka. Perilaku tertutup merupakan bentuk pasif yaitu respon yang terjadi dalam diri seseorang terhadap stimulus yang masih dalam bentuk tertutup (covert). Respon terhadap stimulus ini belum dapat diamati secara jelas oleh orang lain, masih terbatas pada perhatian, persepsi, pengetahuan/kesadaran, dan sikap. Perilaku terbuka merupakan bentuk aktif yaitu respon yang terjadi dalam diri seseorang terhadap stimulus dalam bentuk tindakan nyata atau terbuka (overt). Respon terhadap stimulus ini dapat diamati atau dilihat oleh orang lain dalam bentuk tindakan atau praktik (practice).

Menurut Standard Precautions Clinical Governance (2010), perilaku penggunaan APD oleh tenaga kesehatan harus dilakukan sebagai pemenuhan standar di Rumah Sakit tempat tenaga kesehatan melaksanaan proses pelayanan kesehatan, sebagai tingkat dasar pencegahan dan pengendalian infeksi sehingga dapat mengurangi risiko penularan patogen baik melalui darah atau cairan tubuh pasien yang lain, sebagai pendukung semua kegiatan selama pemberian perawatan pelayanan kesehatan di rumah sakit, seperti tingkat interaksi antara tenaga kesehatan dan pasien maupun tenaga kesehatan yang satu dengan yang lain, serta sebagai penjamin keamanan pasien dan tenaga kesehatan serta orang lain yang mengunjungi lingkungan rumah sakit.

\section{Pengetahuan}

Menurut Notoatmodjo (2012), pengetahuan adalah segala hal yang diketahui mengenai sesuatu yang terjadi setelah seseorang melakukan penginderaan terhadap suatu obyek atau peristiwa. Pengetahuan atau ranah kognitif menjadi dasar penting terbentuknya perilaku seseorang karena perilaku yang didasari oleh pengetahuan akan mempermudah seseorang untuk melakukan suatu perilaku serta akan lebih berlangsung lama dibandingkan dengan perilaku yang tidak didasari oleh pengetahuan, demikian sebaliknya (Syah, 2003; Sakinah, 2017). Pengetahuan berfungsi untuk memperoleh pemahaman, pembelajaran dan pengalaman yang terakumulasi terhadap suatu obyek sehingga dapat diaplikasikan ke dalam perilaku tertentu (Syah, 2003). Pengetahuan tenaga kesehatan mengenai penggunaan APD sangat berperan dalam perilaku kepatuhan penggunaan APD. Jika tenaga kesehatan telah mengetahui 
bahaya dan risiko infeksi di tempat kerja, maka secara otomatis akan melakukan usaha untuk menghindari bahaya dan risiko tersebut, salah satunya dengan menggunakan APD.

\section{Motivasi}

Motivasi adalah suatu perasaan yang mendorong seseorang melakukan suatu perbuatan atau pekerjaan untuk mencapai tujuan yang hendak dicapai (Murdyastuti, 2010). Motivasi dapat berasal dari diri individu (internal) seperti harga diri, harapan, tanggung jawab, pendidikan serta berasal dari lingkungan luar (eksternal) seperti hubungan interpersonal, keamanan dan keselamatan kerja, dan pelatihan (Purwanto, 2009). Menurut Sardiman (2016), motivasi berfungsi untuk menggerakkan dan mendorong timbulnya suatu perbuatan, menentukan arah perbuatan pada tujuan yang hendak dicapai, serta menyeleksi perbuatan yaitu memilih perbuatan yang harus dikerjakan dan yang harus disisihkan untuk mencapai tujuan tertentu. Murdyastuti (2010) menyatakan motivasi tenaga kesehatan dalam perilaku kesehatan dapat diukur dalam 3 indikator yaitu sikap kesungguhan dan keseriusan kerja tenaga kesehatan, sikap dan tanggung jawab tenaga kesehatan dalam bekerja serta sikap yang mencerminkan kebutuhan akan prestasi kerja dan pencapaian hasil kerja.

\section{Persepsi Risiko}

Persepsi risiko adalah pandangan subyektif dari kerentanan yang dirasakan seseorang tentang kemungkinan mengalami suatu kejadian yang tidak dikehendaki dan keparahan konsekuensi negatif dari kejadian tersebut (Masoud, 2013). Persepsi risiko berfungsi untuk menentukan dan mengenal risiko yang akan dihadapi oleh seseorang (Sarlito, 2013). Persepsi risiko merupakan salah satu faktor yang mempengaruhi perilaku kesehatan pada teori Health Belief Model (Model Kepercayaan Kesehatan) yang dikemukakan oleh Rosenstock (1960). Rentannya risiko seseorang mendapatkan suatu penyakit akan membuat individu melakukan perilaku pencegahan atau pengobatan penyakit tersebut. Semakin tinggi risiko yang diyakini seseorang, maka semakin tinggi kemungkinan seseorang tersebut untuk berperilaku sehat seperti melakukan tindakan pencegahan dengan harapan mengurangi risiko tersebut, dan begitu juga sebaliknya, ketika seseorang yakin bahwa mereka tidak berisiko atau mempunyai risiko kecil, maka semakin rendah kemungkinan seseorang untuk berperilaku sehat. Persepsi risiko yang terjadi dapat berdampak pada perilaku kesehatan seseorang terhadap keselamatan seperti perilaku penggunaan APD (Hayden, 2014).

\section{Pengawasan}

Menurut Kurniawan (2009), pengawasan adalah kegiatan yang dilakukan seseorang yang diberi kuasa untuk mengamati, memeriksa, dan memantau kegiatan yang dilakukan tenaga kerja selama bekerja. Pengawasan adalah tanggung jawab pimpinan atau atasan dari suatu kelompok. Pengawasan apabila dijalankan sesuai prosedur akan berdampak positif terhadap kinerja dan perilaku bawahan (Arwani, 2006; Suarli dan Bachtiar, 2009). Fungsi pengawasan ialah untuk memastikan bahwa suatu pekerjaan dilakukan sesuai dengan prosedur dan petunjuk yang telah ditetapkan (Simamora, 2012).

\section{Hipotesis}

Pada penelitian sebelumnya terdapat beberapa perbedaan dari hasil penelitiannya. Penelitian yang dilakukan oleh Nizar (2016), Sakinah (2017), Zahara dkk. (2017), Magita (2017), Nasrulzaman (2018) dan Garudiwati dkk. (2018) menunjukkan adanya pengaruh signifikan pengetahuan tentang penggunaan APD terhadap perilaku penggunaan APD, sedangkan hasil penelitian dari Arifin dkk. (2013) dan Putri (2014) menyatakan bahwa pengetahuan tentang penggunaan APD tidak berpengaruh terhadap perilaku penggunaan APD.

\section{$\mathrm{H}_{1}$ : Pengetahuan tentang penggunaan APD dasar berpengaruh positif terhadap perilaku penggunaan APD dasar}

Penelitian yang dilakukan oleh Murdyastuti (2010), Rotinsulu dkk. (2012), Kasim (2017) dan Kustriyani dkk. (2017) menunjukkan adanya pengaruh yang signifikan motivasi tentang penggunaan APD terhadap perilaku penggunaan APD. 


\section{$\mathrm{H}_{2}$ : Motivasi tentang penggunaan APD dasar berpengaruh positif terhadap perilaku penggunaan APD dasar}

Pada penelitian sebelumnya terdapat beberapa perbedaan dari hasil penelitiannya. Penelitian yang dilakukan oleh Mortada dan Zalat (2013), Yousafzai dkk. (2015), Aung dkk. (2016) dan Powers dkk. (2016) menunjukkan adanya pengaruh yang signifikan persepsi risiko mengenai penggunaan APD terhadap perilaku dalam menggunakan APD, sedangkan hasil penelitian dari Rusmerie (2016) dan Sakinah (2017) menyatakan bahwa persepsi risiko tentang penggunaan APD tidak berpengaruh terhadap perilaku penggunaan APD.

$\mathrm{H}_{3}$ : Persepsi risiko tentang penggunaan APD dasar berpengaruh positif terhadap perilaku penggunaan APD dasar

Rotinsulu dkk. (2012) menemukan adanya pengetahuan dan motivasi tanpa disertai pengawasan dan peraturan yang kurang tegas dari pimpinan membuat banyak Dokter Gigi Muda tidak sungguh-sungguh atau cenderung meremehkan melakukan tindakan kontrol infeksi perilaku penggunaan APD. Penelitian lain oleh Faris dan Harianto (2014) menunjukkan pengawasan tentang penggunaan APD memoderasi motivasi dan persepsi risiko tentang penggunaan APD terhadap perilaku penggunaan APD.

$\mathrm{H}_{4 a}$ : Pengawasan tentang penggunaan APD dasar memoderasi pengaruh pengetahuan tentang penggunaan APD dasar terhadap perilaku penggunaan APD dasar

$\mathrm{H}_{4 \mathrm{~b}}$ : Pengawasan tentang penggunaan APD dasar memoderasi pengaruh motivasi tentang penggunaan APD dasar terhadap perilaku penggunaan APD dasar

$\mathrm{H}_{4 \mathrm{c}}$ : Pengawasan tentang penggunaan APD dasar memoderasi pengaruh persepsi risiko tentang penggunaan APD dasar terhadap perilaku penggunaan APD dasar

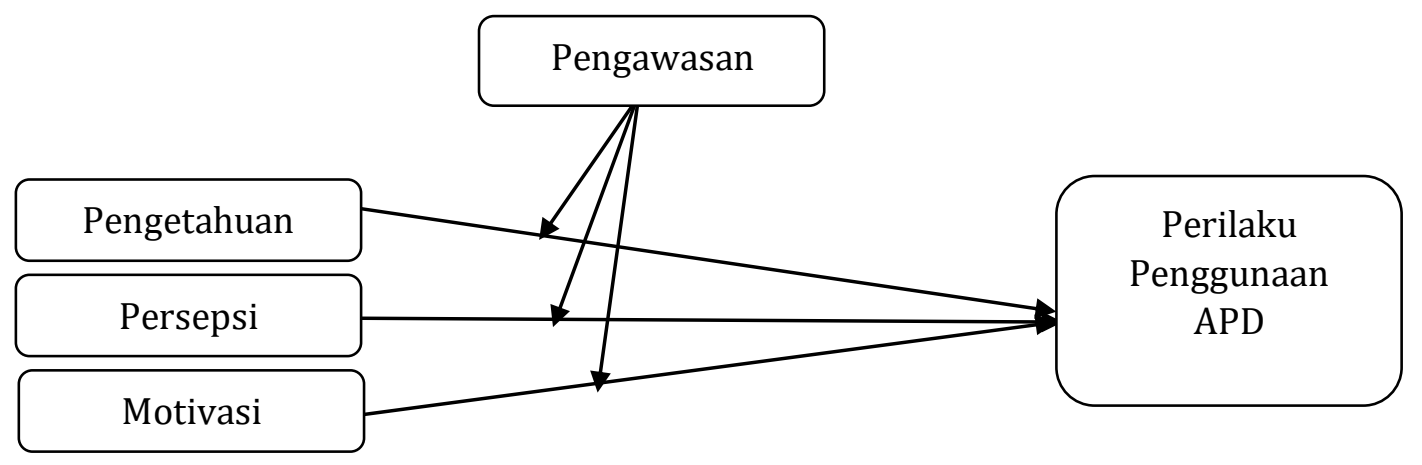

Gambar 1. Model Penelitian

\section{METODOLOGI PENELITIAN}

Penelitian ini menggunakan jenis penelitian kuantitatif dengan rancangan penelitian kausal dan pendekatan cross sectional. Teknik pengambilan sampel yang digunakan dalam penelitian ini adalah teknik proportionate random sampling. Sampel pada penelitian ini adalah seluruh total populasi, yang artinya seluruh tenaga kesehatan yang bekerja secara klinis di RSGMP Unsoed yang berjumlah 127 orang meliputi dokter umum, dokter gigi, perawat umum, perawat gigi, dan mahasiswa profesi dokter gigi.

Metode pengumpulan data yang digunakan dalam penelitian ini adalah wawancara dengan instrumen berupa kuesioner. Skala pengukuran yang digunakan dalam kuesioner ini skala Likert dengan menggunakan rentang skor 1-5. Uji validitas dilakukan menggunakan analisis item yang dikemukakan oleh Pearson yang dikenal dengan korelasi Pearson Product Moment. Uji reliabilitas dilakukan menggunakan metode Cronbach Alpha. Alat analisis penelitian ini adalah regresi moderasi (Moderating Regression Analysis) dengan memanfaatkan program SPSS. 


\section{HASIL PENELITIAN}

\section{Hasil Uji Validitas}

Uji validitas penelitian ini menggunakan korelasi Pearson Product Moment. Nilai $r$ tabel pada 30 responden $(\mathrm{df}=\mathrm{n}-2=28)$ dengan tingkat kemaknaan 0,05 adalah 0,361 . Hasil uji validitas dapat dilihat pada tabel 1 .

Tabel 1. Uji validitas

\begin{tabular}{llccc}
\hline No. & Variabel & r hitung & r tabel & Status \\
\hline 1. & Pengetahuan & $0,449-0,858$ & 0,361 & valid \\
2. & Motivasi & $0,461-0,847$ & 0,361 & valid \\
3. & Persepsi Risiko & $0,450-0,847$ & 0,361 & valid \\
4. & Pengawasan & $0,558-0,809$ & 0,361 & valid \\
5. & Perilaku & $0,506-0,783$ & 0,361 & valid \\
\hline
\end{tabular}

Sumber: Data Primer Terolah, 2019

Tabel 1 menunjukkan dari semua item pertanyaan untuk masing-masing variabel pengetahuan, motivasi, persepsi risiko, pengawasan dan perilaku memiliki nilai $r$ hitung $(0,449$ $0,858)$ yang lebih besar daripada nilai $r$ tabel $(0,361)$. Hal ini menunjukkan bahwa semua item pertanyaan yang diajukan pada penelitian ini adalah valid.

\section{Hasil Uji Reliabilitas}

Uji reliabilitas penelitian ini menggunakan metode Cronbach's Alpha. Instrumen penelitian dinyatakan reliabel apabila nilai $r$ alpha lebih dari 0,6. Hasil uji reliabilitas dapat dilihat pada tabel 2.

Tabel 2. Uji reliabilitas

\begin{tabular}{llccc}
\hline No. & Variabel & r alpha & r tabel & Status \\
\hline 1. & Pengetahuan & 0,876 & 0,600 & reliabel \\
2. & Motivasi & 0,901 & 0,600 & reliabel \\
3. & Persepsi Risiko & 0,856 & 0,600 & reliabel \\
4. & Pengawasan & 0,881 & 0,600 & reliabel \\
5. & Perilaku & 0,755 & 0,600 & reliabel \\
\hline
\end{tabular}

Sumber: Data Primer Terolah, 2019

Tabel 2 menunjukkan dari semua item pertanyaan untuk masing-masing variabel pengetahuan, motivasi, persepsi risiko, pengawasan dan perilaku memiliki nilai $r$ alpha $(0,755-$ 0,901 ) yang lebih besar daripada nilai $r$ tabel $(0,600)$. Hal ini menunjukkan bahwa semua item pertanyaan yang diajukan pada penelitian ini adalah reliabel.

\section{Hasil Uji Hipotesis}

Uji regresi ganda digunakan untuk mengetahui bagaimana pengaruh variabel pengetahuan (X1), motivasi (X2), persepsi risiko (X3) terhadap variabel perilaku (Y). Hasil uji regresi ganda dapat dilihat pada tabel 3.

Tabel 3. Uji regresi ganda

\begin{tabular}{lccccc}
\hline $\begin{array}{l}\text { Variabel } \\
\text { Independen }\end{array}$ & $\begin{array}{c}\text { Variabel } \\
\text { Dependen }\end{array}$ & $\begin{array}{c}\text { R } \\
\text { square }\end{array}$ & $\begin{array}{c}\text { Adjusted } \\
\text { R square }\end{array}$ & $\begin{array}{c}\text { Koefisien } \\
\text { regresi }\end{array}$ & $\begin{array}{c}\text { Nilai } \\
\text { signifikansi }\end{array}$ \\
\hline Pengetahuan & & & & 0,224 & $0,006^{*}$ \\
Motivasi & Perilaku & 0,534 & 0,519 & 0,206 & $0,011^{*}$ \\
Persepsi & & & & 0,239 & $0,006^{*}$ \\
Risiko & & & & & \\
\hline
\end{tabular}

Keterangan : * : berpengaruh $(\mathrm{p}<0,05)$

Sumber: Data Primer Terolah, 2019 
Tabel 3 menunjukkan bahwa nilai R square sebesar 0,534 menunjukkan bahwa 53,4\% dari perilaku diterangkan oleh pengetahuan, motivasi, dan persepsi risiko; sisanya dipengaruhi oleh variabel lain. Variabel pengetahuan (X1), motivasi (X2) dan persepsi risiko (X3) memiliki nilai signifikansi yang lebih kecil daripada nilai $\mathrm{t}_{\text {tabel }}(0,05)$. Hal ini menunjukkan bahwa pengetahuan, motivasi dan persepsi risiko tentang penggunaan APD dasar berpengaruh signifikan terhadap perilaku penggunaan APD dasar.

Uji moderasi digunakan untuk mengetahui apakah variabel pengawasan (Xm) memoderasi pengaruh antara variabel pengetahuan (X1), motivasi (X2), dan persepsi risiko (X3) terhadap variabel perilaku (Y). Hasil uji regresi moderasi dapat dilihat pada tabel 4.

\begin{tabular}{lcccc}
$\begin{array}{l}\text { Tabel 4. Uji regresi moderasi } \\
\text { Variabel }\end{array}$ & $\mathbf{X}$ & $\begin{array}{c}\text { Variabel } \\
\text { moderasi }\end{array}$ & $\begin{array}{c}\text { Koefisien } \\
\text { regresi }\end{array}$ & $\begin{array}{c}\text { Nilai } \\
\text { signifikansi }\end{array}$ \\
\hline Pengetahuan & $\mathrm{X}$ & Pengawasan & $-3,11$ & $0,013^{*}$ \\
Motivasi & $\mathrm{X}$ & Pengawasan & $-2,62$ & $0,044^{*}$ \\
Persepsi Risiko & $\mathrm{X}$ & Pengawasan & $-2,11$ & 0,074 \\
\hline
\end{tabular}

Keterangan : ${ }^{*}$ : berpengaruh $(\mathrm{p}<0,05)$

Sumber: Data Primer Terolah, 2019

Tabel 4 menunjukkan variabel pengetahuan (X1) dan motivasi (X2) memiliki nilai signifikansi yang lebih kecil daripada nilai $t_{\text {tabel }}(0,05)$. Hal ini menunjukkan pengawasan tentang penggunaan APD dasar memoderasi pengaruh pengetahuan dan motivasi tentang penggunaan APD dasar terhadap perilaku penggunaan APD dasar. Namun pada variabel persepsi risiko (X3) memiliki nilai signifikansi yang besar daripada nilai $t_{\text {tabel }}(0,05)$. Hal ini menunjukkan pengawasan tentang penggunaan APD dasar tidak memoderasi pengaruh persepsi risiko tentang penggunaan APD dasar terhadap perilaku penggunaan APD dasar.

\section{PEMBAHASAN}

\section{Pengetahuan tentang Penggunaan Alat Pelindung Diri dasar berpengaruh positif terhadap Perilaku Penggunaan Alat Pelindung Diri dasar}

Hasil penelitian menunjukkan kesesuaian dengan hipotesis penelitian yang menyatakan pengetahuan tentang penggunaan APD dasar berpengaruh ke arah positif terhadap perilaku penggunaan APD dasar. Setiap peningkatan pengetahuan tentang penggunaan APD dasar akan meningkatkan perilaku penggunaan APD dasar sebesar 0,224. Hal ini diperkuat teori perilaku kesehatan oleh Lawrence Green (1980) yang menyatakan bahwa salah satu faktor predisposisi atau faktor dasar dari perilaku yaitu tingkat pengetahuan seseorang. Menurut Azwar (2015), pengetahuan dapat diperoleh dari tiga sumber yaitu pengalaman pribadi langsung, informasi dari lingkungan, serta pendidikan formal atau non formal seperti pelatihan, pengarahan, diskusi, dan lain-lain. Hal ini juga berarti bahwa sumber pengetahuan tersebut mampu membentuk pengetahuan tentang penggunaan APD dasar di RSGMP Unsoed Purwokerto. Setelah tenaga kesehatan memiliki pengetahuan tentang penggunaan APD dasar, kemudian mengadakan penilaian tentang apa yang diketahuinya dalam bentuk sikap, proses selanjutnya diharapkan ia akan melaksanakan atau mempraktikkan apa yang diketahui atau disikapinya, hal inilah yang disebut perilaku penggunaan APD dasar (Notoatmodjo, 2012).

\section{Motivasi tentang Penggunaan Alat Pelindung Diri dasar berpengaruh positif terhadap Perilaku Penggunaan Alat Pelindung Diri dasar}

Hasil penelitian menunjukkan kesesuaian dengan hipotesis penelitian yang menyatakan motivasi tentang penggunaan APD dasar berpengaruh ke arah positif terhadap perilaku penggunaan APD dasar. Setiap peningkatan motivasi tentang penggunaan APD dasar akan meningkatkan perilaku penggunaan APD dasar sebesar 0,206. Motivasi tenaga kesehatan dalam penggunaan APD dasar merupakan salah satu faktor yang mendasari perilaku penggunaan APD dasar yang berasal dari kebutuhan akan rasa aman. Kebutuhan akan rasa aman ini 
menimbulkan keinginan dan harapan seseorang agar terhindar dari berbagai hal yang membahayakan yang berasal dari lingkungan kerja.

Aspek-aspek yang meliputi sikap kesungguhan dan keseriusan kerja tenaga kesehatan, sikap dan tanggung jawab tenaga kesehatan dalam bekerja serta sikap yang mencerminkan kebutuhan akan hasil prestasi dan pencapaian hasil kerja telah membentuk motivasi tentang penggunaan APD dasar yang baik di RSGMP Unsoed Purwokerto. Hasil ini diperkuat dengan pendapat yang disampaikan Hariandja (2002) bahwa motivasi dapat ditimbulkan oleh kebutuhan, daya dorong, keinginan serta keamanan yang merupakan penyebab dan mendasari terjadinya perilaku seseorang. Motivasi tenaga kesehatan dalam penggunaan APD dasar bermanfaat untuk mencegah dan melindungi dirinya dari infeksi nosokomial di RSGMP Unsoed. Motivasi penggunaan APD dasar selain berasal dari kesadaran diri sendiri, juga dapat berasal dari dorongan supervisor atau kepala ruangan.

\section{Persepsi Risiko tentang Penggunaan Alat Pelindung Diri dasar berpengaruh positif terhadap Perilaku Penggunaan Alat Pelindung Diri dasar}

Hasil penelitian menunjukkan kesesuaian dengan hipotesis penelitian yang menyatakan persepsi risiko tentang penggunaan APD dasar berpengaruh ke arah positif terhadap perilaku penggunaan APD dasar. Setiap peningkatan persepsi risiko tentang penggunaan APD dasar akan meningkatkan perilaku penggunaan APD dasar sebesar 0,239. Hal ini juga berarti bahwa aspekaspek yang meliputi tanggung jawab terhadap diri sendiri dan pasien atas risiko finansial, waktu maupun keamanan dalam bekerja telah membentuk persepsi risiko tentang penggunaan APD dasar yang baik di RSGMP Unsoed Purwokerto. Persepsi risiko tenaga kesehatan apabila tidak menggunakan APD dasar di RSGMP Unsoed ialah merasa rentan terhadap semua infeksi nosokomial yang dapat timbul saat bekerja. Persepsi tersebut membuat tenaga kesehatan mengetahui tentang keparahan serta manfaat yang lebih besar dari hambatan yang dirasakan sehingga mereka mempunyai dorongan untuk berperilaku menggunakan APD dasar saat bekerja. Hal ini diperkuat oleh teori Health Belief Model yang menyatakan bahwa persepsi akan mempengaruhi seseorang dalam berperilaku (Redding dkk., 2000; Firman, 2015).

Nilai beta paling tinggi pada variabel persepsi risiko menunjukkan bahwa persepsi risiko memberikan perubahan paling tinggi terhadap perilaku penggunaan APD dasar dibandingkan dua variabel lainnya yaitu pengetahuan dan motivasi. Hal ini sejalan dengan penelitian Yousafzai dkk. (2015) yang menyatakan bahwa tingkat persepsi risiko responden berpengaruh positif terhadap perilaku penggunaan APD. Gibson dkk. (2007) mengemukakan bahwa perilaku dan performance seseorang dipengaruhi oleh berbagai macam faktor psikologis, salah satunya yaitu persepsi risiko seseorang. Persepsi risiko akan mempengaruhi pengambilan keputusan seseorang dan keputusan tersebut akan mendorong seseorang untuk melakukan suatu perilaku untuk mencapai tujuannya. Oleh karena itu pada penelitian ini persepsi risiko tenaga kesehatan tentang penggunaan APD akan menimbulkan suatu perilaku penggunaan APD dasar di RSGMP Unsoed.

\section{Pengawasan tentang penggunaan Alat Pelindung Diri dasar memoderasi pengaruh pengetahuan tentang penggunaan Alat Pelindung Diri dasar terhadap perilaku penggunaan Alat Pelindung Diri dasar}

Hasil penelitian menunjukkan kesesuaian dengan hipotesis penelitian yang menyatakan pengawasan tentang penggunaan APD dasar memoderasi pengaruh pengetahuan tentang penggunaan APD dasar terhadap perilaku penggunaan APD dasar namun dengan arah moderasi negatif. Hasil ini sejalan dengan penelitian Rotinsulu dkk. (2012) yang menyatakan bahwa pengawasan memoderasi pengaruh pengetahuan dan motivasi terhadap perilaku penggunaan APD dasar. Pengawasan sebagai variabel moderasi pada penelitian ini merupakan salah satu faktor reinforcing yang memperkuat terjadinya perilaku seseorang (Lawrence Green, 1980). Namun pada penelitian ini, pengawasan penggunaan APD dasar menjadi faktor yang memperlemah pengetahuan penggunaan APD dasar terhadap perilaku penggunaan APD dasar karena proses pengawasan yang dilakukan oleh supervisor/kepala ruangan belum berjalan dengan baik. Pada penelitian ini dimana tenaga kesehatan di RSGMP Unsoed telah mengetahui 
jenis, kegunaan, syarat, dan dampak dari penggunaan APD dasar, namun masih belum mengetahui secara jelas proses pengawasan yang dilakukan oleh tim supervisor/kepala ruangan maupun tim PPI misalnya jadwal pengawasan yang belum rutin setiap harinya maupun penetapan sanksi yang belum tegas sehingga membuat tenaga kesehatan memiliki kemungkinan kesempatan untuk tidak menggunakan APD dasar dengan baik.

\section{Pengawasan tentang penggunaan Alat Pelindung Diri dasar memoderasi pengaruh motivasi tentang penggunaan Alat Pelindung Diri dasar terhadap perilaku penggunaan Alat Pelindung Diri dasar}

Hasil penelitian menunjukkan kesesuaian dengan hipotesis penelitian yang menyatakan pengawasan tentang penggunaan APD dasar memoderasi pengaruh motivasi tentang penggunaan APD dasar terhadap perilaku penggunaan APD dasar namun dengan arah moderasi negatif. Motivasi merupakan perasaan yang mendorong seseorang untuk melakukan suatu perilaku (Sardiman, 2016). Pada dasarnya, manfaat dari adanya pengawasan oleh supervisor atau kepala ruangan dalam penggunaan APD dasar ialah termotivasinya tenaga kesehatan untuk selalu menggunakan APD dasar secara benar sesuai dengan fungsinya. Namun, justru dengan adanya pengawasan tersebut membuat tenaga kesehatan di RSGMP Unsoed merasa under pressure dan tidak leluasa untuk berinisiatif menggunakan APD dasar sehingga membuat turunnya motivasi dari tenaga kesehatan itu sendiri dalam menggunakan APD dasar. Mayoritas responden memiliki profesi sebagai mahasiswa profesi kedokteran gigi yaitu sebesar 95 responden $(74,8 \%)$, karena RSGMP Unsoed selain sebagai sarana pelayanan kesehatan, namun juga berperan sebagai sarana pendidikan untuk mahasiswa profesi kedokteran gigi (Profil RSGMP Unsoed, 2015). Banyaknya mahasiswa profesi tersebut dengan usia yang masih tergolong muda ( $<25$ tahun) membuat perilaku yang ditampilkan pun menjadi lebih labil dan cenderung tidak nyaman apabila bekerja dibawah tekanan. Hal ini didukung oleh penelitian Siagian (2012) yang menyatakan bahwa usia sangat erat kaitannya dengan produktifitas seseorang dan tingkat kedewasaan baik secara teknis maupun psikologis.

\section{Pengawasan tentang penggunaan Alat Pelindung Diri dasar tidak memoderasi pengaruh persepsi risiko tentang penggunaan Alat Pelindung Diri dasar terhadap perilaku penggunaan Alat Pelindung Diri dasar}

Hasil penelitian menunjukkan ketidaksesuaian dengan hipotesis penelitian yang menyatakan pengawasan tentang penggunaan APD dasar tidak memoderasi pengaruh persepsi risiko tentang penggunaan APD dasar terhadap perilaku penggunaan APD dasar. Hal ini tidak sejalan dengan penelitian Faris dan Harianto (2014) yang menyatakan bahwa pengawasan tentang penggunaan APD memoderasi motivasi dan persepsi risiko tentang penggunaan APD terhadap perilaku penggunaan APD. Persepsi risiko tentang penggunaan APD dasar merupakan salah satu faktor internal yang dapat membentuk perilaku tenaga kesehatan dalam penggunaan APD dasar. Persepsi risiko timbul berdasarkan pandangan subyektif tenaga kesehatan terhadap kemungkinan suatu kondisi bahaya. Pengawasan dalam penelitian ini kemungkinan bukanlah hal yang mendorong terbentuknya persepsi risiko karena responden yang telah memahami risiko dari infeksi nosokomial yang akan terjadi di RSGMP Unsoed akan secara otomatis menerapkan perilaku penggunaan APD dasar dengan baik sehingga tidak diperlukan faktor pengawasan lagi. Ada kemungkinan faktor eksternal lain seperti ketersediaan fasilitas, sanksi, dan reward yang lebih dapat memoderasi pengaruh persepsi risiko terhadap perilaku penggunaan APD dasar. Hal ini sejalan dengan teori perspektif interaksionis yaitu pembentukan perilaku dapat dipengaruhi oleh faktor internal dan faktor eksternal. Faktor eksternal adalah faktor yang berasal dari lingkungan seseorang, misalnya ketersediaan fasilitas, sanksi, reward maupun pengawasan (Hayden, 2014). 


\section{KESIMPULAN}

Berdasarkan hasil penelitian dapat disimpulkan bahwa terdapat pengaruh pengetahuan, motivasi dan persepsi risiko tentang penggunaan APD dasar terhadap perilaku penggunaan APD dasar. Pengawasan memoderasi pengaruh pengetahuan dan motivasi terhadap perilaku penggunaan APD dasar, namun tidak memoderasi pengaruh persepsi risiko terhadap perilaku penggunaan APD dasar.

\section{IMPLIKASI MANAJERIAL}

Berdasarkan hasil analisis dan kesimpulan, diharapkan penelitian ini dapat memberikan manfaat bagi RSGMP Unsoed dalam hal penggunaan Alat Pelindung Diri dasar untuk mencegah dan mengendalikan infeksi nosokomial. RSGMP Unsoed diharapkan dapat mempertahankan faktor-faktor yang mempengaruhi perilaku penggunaan Alat Pelindung Diri dasar seperti pengetahuan, motivasi dan persepsi risiko dengan memasang banner-banner pengingat tentang pentingnya perilaku penggunaan Alat Pelindung Diri dasar di setiap sudut RSGMP Unsoed. RSGMP Unsoed terutama bagian tim PPI lebih mengoptimalkan penerapan kewaspadaan standar dan melakukan proses pengawasan secara rutin dalam penerapan budaya keselamatan agar pelayanan kesehatan di RSGMP Unsoed menjadi lebih aman dan terhindar dari kejadian yang tidak diinginkan serta dapat mengembangkan dan menggali faktor-faktor lain yang mungkin dapat mempengaruhi tingkat perilaku penggunaan Alat Pelindung Diri dasar.

Keterbatasan penelitian ini adalah penelitian ini meneliti pengaruh pengetahuan, motivasi dan persepsi risiko serta moderasi pengawasan terhadap perilaku penggunaan Alat Pelindung Diri dasar. Pengawasan merupakan salah satu faktor eksternal yang diteliti oleh peneliti. Faktor eksternal lain selain faktor pengawasan tidak diteliti lebih lanjut pada penelitian ini.

\section{SARAN}

Saran yang dapat diberikan untuk penelitian selanjutnya yaitu pengembangan penelitian lebih lanjut mengenai faktor eksternal lain selain faktor pengawasan yang dapat memoderasi perilaku penggunaan Alat Pelindung Diri dasar serta menggunakan metode penelitian yang lain, seperti metode observasi yaitu menilai secara langsung perilaku penggunaan Alat Pelindung Diri dasar oleh supervisor / kepala ruangan.

\section{DAFTAR PUSTAKA}

Arifin, A. B., Susanto, A., Ilham. (2013). Faktor-Faktor yang Berhubungan dengan Kepatuhan Pekerja Dalam Pemakaian Alat Pelindung Diri (APD) di Bagian Coal Yard RT X Unit 3 \& 4 Kabupaten Jepara Tahun 2012. Jurnal Kesehatan Masyarakat. 2 (1): 12-23.

Arwani. (2006). Pendidikan Keperawatan. Jakarta: EGC.

Aung S.S., Nursala, Dewi, Y.S. (2016). Improving Compliance with Standard Precautins Among Myanmar Nurses Using Health Belief Model. The Malaysian Journal of Nursing. 8(2): 21-28.

Azwar, S. (2015). Sikap manusia; Teori dan Pengukurannya. Yogyakarta, Pustaka Pelajar.

Darmadi. (2008). Infeksi Nosokomial: Problematika dan Pengendaliannya. Jakarta: Salemba Medika.

Faris, I.A dan Harianto, F. (2014). Pengaruh Persepsi, Motivasi dan Lingkungan Kerja yang di Moderasi Faktor Pengalaman Kerja dan Pengawasan Terhadap Kecelakaan Kerja Konstruksi di Surabaya. Jurnal Teknik Sipil ITS. 3(1): 1-16.

Firman, M. S. (2015). Analisis Faktor yang Berhubungan dengan Kepatuhan Minum Obat Pasien TB Paru berdasarkan Health Belief Model di wilayah kerja Puskesmas Umbulsari, Kabupaten Jember. Jurnal Ilmu Keperawatan Unirversitas Airlangga. 6(2): 8-17.

Garudiwati, B.D., Kusumawati, W., Arini, M. (2018). Pengaruh Determinan Perilaku terhadap Kepatuhan Perawatan Menggunakan Alat Pelindung Diri (APD) di Rumah Sakit Swasta Yogyakarta. Jurnal Manajemen. 1(2): 1-14.

Geller, E., Scott. (2001). Working Safe: How to Help People Actively Care for Health and Safety. Florida: Lewis Publishers.

Gibson, JL, Ivancevich, J.M., Donelly. (2007). Organization Behaviour Structure Processes. Unites States of America. Van Hoffman Press. 
Green, Lawrence. (1980). Health Educationing Planning, A Diagnostic Approach. California: Mayfield Publishing.

Hariandja. (2002). Faktor-Faktor Yang Berhubungan Dengan Kepatuhan Perawat Dan Bidan Dalam Menerapkan Kewaspadaan Standar Di Rumah Sakit Palang Merah Indonesia Bogor Tahun 2001. Jurnal Kesehatan Masyarakat Universitas Indonesia. 1(2): 41-59.

Hayden, J.A. (2014). Introduction to Health Behavior Theory, Second Edition. Burlington: Jones and Bartlett.

Kasim, Y., Mulyadi, Kallo, V. (2017). Hubungan Motivasi dan Supervisi dengan Kepatuhan Perawat dalam Penggunaan Alat Pelindung Diri Pada Penanganan Pasien Gangguan Muskuloskeletal di IGD RSUP Prof. Dr. R.D. Kandou Manado. Jurnal Keperawatan. 5(1): 56-66.

Kurniawan, I. (2009). Gambaran Perilaku Penggunaan Alat Pelindung Diri Pada Pekerja Laundry Rumah Sakit. Tesis. Universitas Indonesia. Depok.

Kustriyani, M., Susanti, A.K., Arifianto. (2017). Hubungan Antara Motivasi Perawat dengan Kepatuhan Penggunaan Alat Pelindung Diri (Handscoon dan Masker di Instalasi Rawat Inap RSUD dr.Loekmono Hadi Kudus. Jurnal Keperawatan. 1(3): 4-11.

Magita, E.Y. (2017). Hubungan Tingkat Pengetahuan APD dengan Kepatuhan Pemakaian APD Masker pada Pekerja Bagian Pelentingan PT Panen Boyolali. Jurnal Kesehatan Masyarakat. 4 (1): 26-32.

Masoud, E.Y. (2013). The Effect of Perceived Risk on Hospital. European Health-Care Journal. 5(6):12-32.

Mortada, E. M. \& Zalat, M. M. (2013). Assessment of Compliance to Standard Precautions among Surgeons in Zagazig University Hospitals, Egypt, using the Health Belief Model. Journal of the Arab Society for Medical Research. 9(1): 6-14.

Murdyastuti, S. (2010). Pengaruh Profesionalitas, Motivasi dan Pengetahuan terhadap Pelaksanaan Program Patient Safety di Ruang Rawat Inap RSO Prof. Dr. R. Soeharso Surakarta. Jurnal Manajemen. 2(3): $12-24$.

Nasrulzaman dan Hasibuan, A. (2018). Analisis Perilaku, Ketersediaan, dan Pengawasan Penggunaan Alat Pelindung Diri di Perusahaan Meubel X. Buletin Utama Teknik. 13(2): 71-81.

Nizar, M.F., Tuna H., Suwaningrum, N.D. (2016). Hubungan Karakteristik Pekerja dengan Kepatuhan Dalam Pemakaian Alat Pelindung Diri pada Petugas Laboratorium Klinik di Rumah Sakit Baptis Kota Mandiri. Jurnal Preventia. 1(1): 1-6.

Notoatmodjo, Soekidjo. (2007). Kesehatan Masyarakat Ilmu dan Seni. Jakarta: PT Rineke Cipta.

Notoatmodjo, Soekidjo. (2012). Promosi Kesehatan dan Perilaku Kesehatan. Jakarta: PT. Rineka Cipta.

Powers, D. P., Armellino, D., Dolansky, M. \& Fitzpatrick, J. (2016). Factors infuencing nurse compliance with Standard Precautions. American Journal of Infection Control. 44(1): 4-6.

Purwanto, B. Y. (2009). Analisis Faktor-Faktor yang Mempengaruhi Perilaku Penggunaan APD Pada Pekerja Las di Jalan Raya Kelapa Dua Tanggerang. Jurnal Fakultas Kesehatan Masyarakat. 2(3): 4-9.

Putri, K.D.S. \& Denny, Y.A.W. (2014). Analisis Faktor yang Berhubungan dengan Kepatuhan Menggunakan Alat Pelindung Diri. The Indonesian Journal of Occupational Safety, Health and Environtment. 1(1): 24-36.

Redding, dkk. (2000). Health Behavior Model. The International Electronic Journal of Health Education. 3(2): 180-193.

Rosenstock, I.M. (1960). The Health Belief Model and Preventive Health Behavior, Fourth Ed. San Fransisco: Jossey Bass.

Rotinsulu, R.A.L., Umboh, J.M.L., Pongoh, J. (2012). Pengaruh Pengetahuan, Ketersediaan Sarana, dan Motivasi dengan Kepatuhan Penerapan Kewaspadaan Standar Oleh Dokter Gigi di Poliklinik Gigi dan Mulut Rumah Sakit Kota Manado. Jurnal Ilmu Kesehatan Masyarakat. 1(4): 64-80

Rusmerie, Lis Andriana R. (2016). Aplikasi Health Belief Model Untuk Menganalisis Pelaporan Kejadian Kecelakaan Kerja (Studi Kasus di rumah Sakit Suaka Insan Banjarmasin). Jurnal Kesehatan Masyarakat Universitas Airlangga. 4(7): 17-26.

Sakinah. (2017). Aplikasi Health Belief Model dalam Menganalisis Perilaku Penggunaan Kacamata Pelindung. Jurnal Promkes. 5(1): 105-116.

Sardiman, A. M. (2016). Interaksi dan Motivasi Belajar Mengajar. Jakarta: Grafindo

Sarlito, W.S. (2013). Hubungan Antara Persepsi Lingkungan Kerja Fisik dengan Perilaku Keselamatan Karyawan. Kalimantan Selatan: Ecopsy.

Siagian. (2012). Pengaruh Pengawasan dan Kepatuhan terhadap Penggunaan Alat Pelindung Diri Pada Perawat dalam Pencegahan Infeksi Nosokomial di Rumah Sakit Umum Daerah Kisaran. Tesis. Universitas Sumatera Utara. Medan.

Simmamora. (2012). Buku Ajar Manajemen Keperawatan. Jakarta: EGC.

Suarli \& Bachtiar. (2009). Manajemen Keperawatan dengan Pendekatan Praktik. Jakarta: Erlangga.

Syah, Muhibin. (2003). Psikologi Belajar. Jakarta: Rajagrafindo. 
Shara, A. C., G. Aditya., B. Benyamin. (2014). Hubungan Antara Pengetahuan Terhadap Motivasi Dokter Gigi Muda dalam Kontrol Infeksi. Studi terhadap Dokter Gigi Muda di Rumah Sakit Islam Gigi dan Mulut Sultan Agung. Medali Jurnal Media Dental Intelektual. 2(1):42-47.

Wijayanto, W. (2015). Hubungan Motivasi Perawat Dengan Perilaku Pemakaian Alat Pelindung Diri Saat Melakukan Kemoterapi Di Ruang Rawat Inap RSUD dr. Moewardi Surakarta. Jurnal Keperawatan. 6(1): 1-17.

Yousafzai, M.T., Janjua, N.Z., Siddiqui, A,R., Rozi, S. (2015). Barriers and Facilitators of Compliance with Universal Precautions at First Level Health Facilities in Notrhern Rural Pakistan. International Journal of Health Sciences Qassim University. 9(4): 388-399.

Zahara, R.A, Effendi, S.U., Khairani, N. (2017). Kepatuhan menggunakan Alat Pelindung Diri ditinjau dari Pengetahuan dan Perilaku Petugas Instalasi Pemeliharaan Sarana dan Prasarana Rumah Sakit. Jurnal Ilmu Kesehatan. 2(2): 148-154. 